Abstracta Iranica

Revue bibliographique pour le domaine irano-aryen

Volume 23 | 2002

Comptes rendus des publications de $\mathbf{2 0 0 0}$

\title{
« Kāmpiyūter dar Hedmat-e adabiyāt-e fārsī ». Našr-e Dāneš, 17, 3 (1379/2000), pp. 2-3.
}

\section{Rédaction}

\section{(2) OpenEdition}

Journals

Édition électronique

URL : http://journals.openedition.org/abstractairanica/35826

DOI : 10.4000/abstractairanica.35826

ISSN : 1961-960X

Éditeur :

CNRS (UMR 7528 Mondes iraniens et indiens), Éditions de l'IFRI

Édition imprimée

Date de publication : 15 mai 2002

ISSN : 0240-8910

Référence électronique

Rédaction, « « Kāmpiyūter dar hedmat-e adabiyāt-e fārsī ». Našr-e Dāneš, 17, 3 (1379/2000), pp. 2-3. », Abstracta Iranica [En ligne], Volume 23 | 2002, document 281, mis en ligne le 08 février 2010, consulté le 25 septembre 2020. URL : http://journals.openedition.org/abstractairanica/35826 ; DOI : https:// doi.org/10.4000/abstractairanica.35826

Ce document a été généré automatiquement le 25 septembre 2020.

Tous droits réservés 


\section{« Kāmpiyūter dar Hedmat-e adabiyāt-e fārsī ». Našr-e Dāneš, 17, $3(1379 / 2000)$, pp. $2-3$.}

Rédaction

Il faut souhaiter un écho efficace des plus hautes instances à cet article énergique, qui énumère les immenses facilités qu'apporteraient à la recherche en littérature persane la mise en ordinateur des grands textes persans.

INDEX

Thèmes : 11.1.1. Littérature persane classique

\section{AUTEURS}

\section{RÉDACTION}

Directeur de la revue et secrétariats (Paris et Téhéran) 